\title{
Hematological Characterization of Horned Viper (Ammodytes ammodytes)
}

\author{
Roxana LAZĂR, Paul C. BOIŞTEANU \\ Department of Fundamental Sciences in Animal Husbandry, University of Agricultural Sciences and \\ Veterinary Medicine Iaşi, Romania \\ *Corresponding author, email: lazarrxn24@yahoo.com
}

Bulletin UASVM Animal Science and Biotechnologies 71(2) / 2014,

Print ISSN 1843-5262; Electronic ISSN 1843-536X

DOI:10.15835/buasvmcn-asb:10556

\begin{abstract}
Assessment of hematological parameters offers the possibility of identifying functional relationships between tissues and viscera and the manifestation of vital functions.

The aim of this paper was to characterize the horned viper (Ammodytes ammodytes) from the necessity of customizing hematological aspects of the species towards the literature classification. The work consisted on morphological examinations and determinations of red blood cells, white blood cells, hemoglobin, hematocrit and red blood cells constant that are necessary for a rigorous characterization of hematological status in horned viper. It is known that blood reacts sensitive to changes produced by the external factors for the entire body. The results reflect differences between males and females in terms of blood and array morphological parameters useful in hematological characterization. Elements of the blood also fulfill a significant role in maintaining unity correlative functional and reactive animal body. Any change to the state of balance in the composition of the internal environment necessary to maintain life, tends to be quickly corrected by appropriate reactions from certain organs, both in physiological conditions and in disease states (Mitchell, 2008). For a good understanding of changes, which occurs in hematological profile and also for the interpretation of how growth conditions influence them, we consider useful to describe the blood elements at horned vipers (Ammodytes ammodytes).
\end{abstract}

Keywords: hematological parameters, horned viper, morphological

Introduction. Determination of hematological and biochemical parameters can be very important in studying the biology of species and in characterization of the health status or animals reproducing bred in captivity or in their natural environment (Canfield, 1998).

Aims and objectives. The purpose of this paper is to characterize the physiological status of horned vipers by comparing the results with those from the literature.

Materials and methods. The research was carried out on 9 horned vipers (Ammodytes ammodytes), 5 females and 4 males, from which were taken blood samples in order to determine hematological parameters. Measurements were made using a standard Natt-Harrick solution, blood counts being complete (erythrocyte parameters, leukocyte and platelet) (Campbell, 2007).
Results and discussion. From the analysis of Table 1 can be observed that females have lower values of leukocyte $7.2 \times 10^{3}$, than males, which have a value of $11.2 \times 10^{3}$. Regarding the number of red blood cells, it is higher in females $\left(0.8 \times 10^{6}\right)$ than $0.4 \times 10^{6}$, in males. Female hemoglobin is 8.3 $\mathrm{g} / \mathrm{dl}$, being superior to the males that have a value of $5.9 \mathrm{~g} / \mathrm{dl}$. Instead, hematocrit is $23 \%$ in female and $24 \%$ in male.

Mean corpuscular volume in females is of 287.5 $\mu \mathrm{m}^{3}$, and in males is higher with a value of $600 \mu \mathrm{m}^{3}$. Mean corpuscular hemoglobin have lower values in females compared with those of males, respectively $103.75 \mathrm{pg}$ of and $147.5 \mathrm{pg} \delta$. Regarding mean corpuscular hemoglobin concentration, the females present a value of $36 \mathrm{~g} / \mathrm{dL}$, being superior to those of males, the last one having a value of $24.58 \mathrm{~g} / \mathrm{dL}$. The obtained values are lower to the values cited on wild population in the specialty literature (Lisičić, 2013). 
Tab. 1. Hematological parameters in horned viper

\begin{tabular}{ccccccccc}
\hline \multirow{2}{*}{ Gender } & \multirow{2}{*}{ Age } & $\begin{array}{c}\text { WBC } \\
\left(\times 10^{3}\right)\end{array}$ & $\begin{array}{c}\text { RBC } \\
\left(\times 10^{6}\right)\end{array}$ & $\begin{array}{c}\mathrm{Hb} \\
\mathrm{g} / \mathrm{dl}\end{array}$ & $\begin{array}{c}\mathrm{Ht} \\
(\%)\end{array}$ & $\begin{array}{c}\mathrm{MCV} \\
\left(\mu \mathrm{m}^{3}\right)\end{array}$ & $\begin{array}{c}\mathrm{MCH} \\
(\mathrm{pg})\end{array}$ & $\begin{array}{c}\mathrm{MCHC} \\
(\mathrm{g} / \mathrm{dL})\end{array}$ \\
\hline+ & 5 & 7.2 & 0.8 & 8.3 & 23 & 287.5 & 103.75 & 36 \\
\hline 0 & 4 & 11.2 & 0.4 & 5.9 & 24 & 600 & 147.5 & 24.58 \\
\hline
\end{tabular}

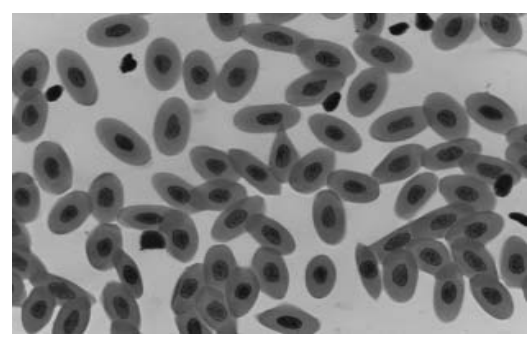

Fig. 1. T The aspect of erythrocytes Col. MGG, x100

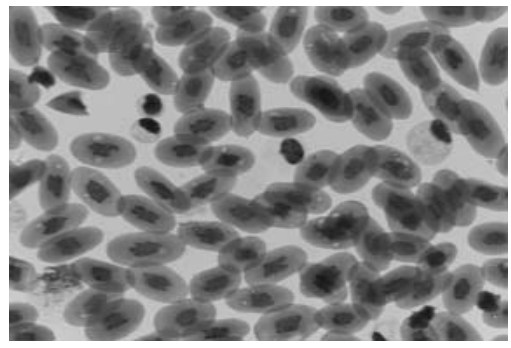

Fig. 4. The aspect of lymphocytes. Col. MGG, x100

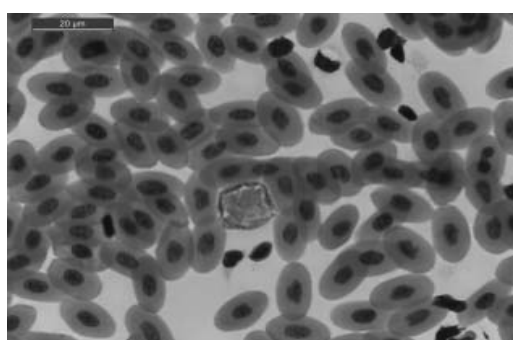

Fig. 2. The aspect of eosinophils. Col. MGG, x100

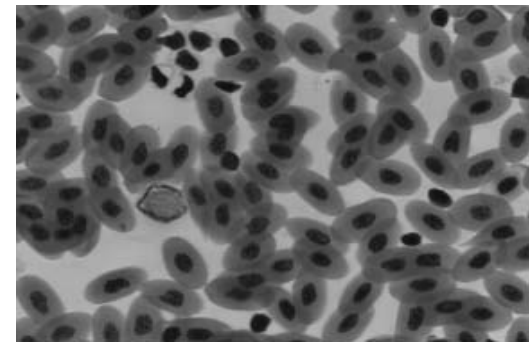

Fig. 5. The aspect of platelets. Col. MGG, x100

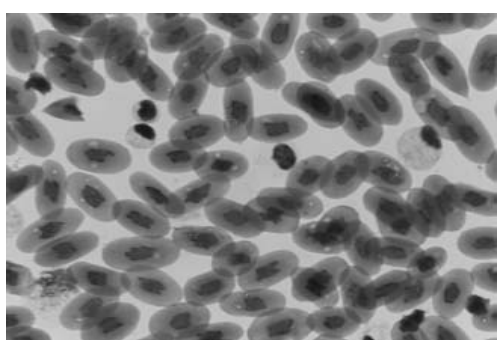

Fig. 3. The aspect of heterophils.Col. MGG, x100

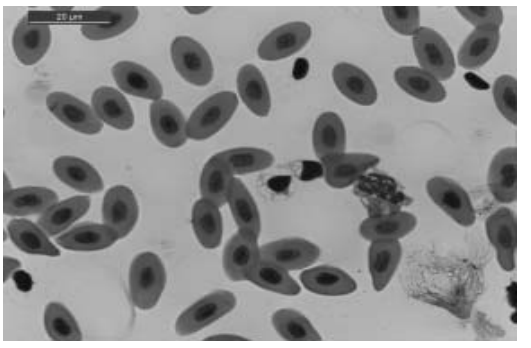

Fig. 6. The aspect of basophils. Col. MGG, x100
The erythrocytes have abundant cytoplasm colored in orange-pink, being often present those with fusiform and tear drop shapes. Eosinophils present clear cytoplasm with pink round grains. The nucleus is centrally or eccentrically located. Heterophils are equivalent to mammalian neutrophils. The cells are large, have round form with clear cytoplasm and orange-pink granulation. Characteristic for reptilian are the angular granulations. It presents eccentric nuclei ranging from round to oval. It is also seen a sufficient number of small punctiform and basophilic inclusions and clear vacuoles.

The lymphocytes identification was also a challenge, because in reptiles they are similar to those of mammals, being easily confused on smear with platelets. Basophils contain small granules, round and dark purple nucleus. The cytoplasm is light purple with clear and distinct vacuoles. Monocytes can be round or angular with distinct cytoplasmic membrane and abundant pale blue- green cytoplasm. The nucleus is kidney-shaped or multilobal.

Conclusion. Making this research on horned vipers allowed us to realize a radiography in terms of their hematological status and correcting growing conditions depending on the physiological status of the organism.

\section{REFERENCES}

1. Canfield PJ (1998). Comparative cell morphology in the peripheral blood film from exotic and native animals. Aust Vet J 76:793-800.

2. Mitchell M, Tully Jr. TN (2008). Manual of Exotic Pet Practice, ed. I. ISBN: 978-1-4160-0119-5.

3. Campbell TW, Ellis CK (2007). Avian and Exotic Animal Hematology and Cytology, ed. 3. ISBN-10:0813818117.

4. Duje Lisičić, Domagoj Đikić, Vesna Benković, Anica Horvat Knežević, Nada Oršolić and Zoran Tadić (2013). Biochemical and hematological profiles of a wild population of the nose-horned viper Vipera ammodytes (Serpentes: Viperidae) during autumn, with a morphological assessment of blood cells. Zoological Studies, 52:11. 